\title{
TERAPI MUROTTAL EFEKTIF MENURUNKAN TINGKAT NYERI DIBANDING TERAPI MUSIK PADA PASIEN PASCABEDAH
}

\author{
Eldessa Vava Rilla ${ }^{1}$, Helwiyah Ropi ${ }^{2}$, Aat Sriati $^{3}$ \\ 1. STIKes Karsa Husada Kabupaten Garut, Tarogong Kidul, Garut 44151, Indonesia \\ 2. Program Studi Magister Fakultas Keperawatan, Universitas Padjadjaran, Teaching Hospital Universitas \\ Padjadjaran, Bandung 40161, Indonesia \\ *E-mail: eldessavavarilla@ymail.com
}

\begin{abstract}
Abstrak
Tindakan pembedahan dapat menimbulkan nyeri dan perubahan tanda-tanda vital. Penelitian ini bertujuan untuk mengidentifikasi perbandingan efektivitas terapi musik dan terapi murottal terhadap penururunan tingkat nyeri dan kestabilan tanda-tanda vital pada pasien pascabedah. Penelitian kuasi eksperimen dengan pendekatan Pretest-Posttest Control Group ini melibatkan 36 responden. Pengukuran tingkat nyeri menggunakan Numerik Rating Scale. Hasil penelitian menunjukkan terdapat perbedaan antara terapi murottal dan terapi musik pada penurunan tingkat nyeri. Rerata penurunan nyeri pada kelompok terapi murottal lebih besar dibandingkan dengan penurunan nyeri dengan pada kelompok terapi musik. Akan tetapi, penelitian ini tidak menemukan perbedaan pada kestabilan tanda-tanda vital antara kelompok yang diberikan terapi murottal dan terapi musik. Terapi murottal dapat menjadi pertimbangan sebagai terapi non farmakologis untuk menurunkan tingkat nyeri pada pasien muslim setelah tindakan pembedahan.
\end{abstract}

Kata kunci: Kestabilan tanda-tanda vital, pascabedah, terapi murottal, terapi musik, tingkat nyeri

\begin{abstract}
Murottal Therapy Reduces Pain Level Effevtively Compare to Music Therapy on the Post Surgery Patients. Surgery causes painful and vital signs alteration. The objective of this study was to compare the effectiviness of music therapy and murottal therapy on reducing of the pain level and stability of vital signs in post surgery patiens. This quasi experimental with pretest-posttest control group study involved 36 respondents. Numeric Rating Scale was used to measure pain level. The result showed that there was significantly difference between murottal therapy and music therapy in reducing pain level. The average of pain level on murottal therapy group was higher than pain level in the music therapy group. On contrary, there no diffirence on average of vital signs stability of both murottal dan musc therapy groups. The murottal therapy should considere as non-pharmacologic measures to reduce pain level in postsurgery patients.
\end{abstract}

Keywords: Murottal therapy, music therapy, pain, post-surger, vital signs stability

\section{Pendahuluan}

Nyeri merupakan salah satu keluhan tersering pada pasien setelah mengalami pembedahan terutama jenis operasi besar seperti laparatomi. Pasien umumnya mengalami nyeri 2-24 jam pertama pascabedah, yaitu ketika pengaruh anastesi sudah hilang, dan pasien sudah keluar dari ruang pemulihan (Apfelbaum, Chen, Mehta, \& Gan, 2003 \& McGrath, 2004).

Pada orang yang tidak mampu mengontrol nyeri akan terjadi disharmoni dalam tubuh. Hal ini bila tidak segera diatasi akan berakibat buruk dengan meningkatnya tanda vital, seperti tekanan darah, nadi, pernapasan, suhu, dan juga pendarahan sehingga memperlambat proses penyembuhan (Apfelbaum, et al., 2003).

Tanda-tanda vital merupakan indikator status kesehatan yang menandakan efektivitas sirkulasi, respirasi, fungsi sarafdan endokrin. Pengukuran tanda-tanda vital memberikan data dasar untuk mengetahui respon terhadap stress fisiologi dan psikologi, rangsangan nyeri, respon terhadap terapi serta perubahan fisiologis (Pacagnella et al., 2013). 
Pada kondisi ini, pasien sangat membutuhkan manajemen nyeri. Manajemen nyeri yang tepat adalah yang mencakup semua aspek nyeri, seperti fisik dan psiko-kognitif (McGrath, 2004). Terdapat dua pendekatan manajemen nyeri pascabedah yaitu secara farmakologis dan non farmakologis. Secara farmakologis mencakup pemberian obatobatan seperti analgetik dan analgesik. Pemberian obat-obatan ini harus tepat karena dapat menimbulkan efek samping adiksi. Pemberian obat jenis narkotika tidak terlalu dianjurkan karena dapat mengaburkan diagnosis. Cara non-farmakologis, seperti distraksi dapat digunakan untuk melengkapi. Ada berbagai macam teknik distraksi, diantaranya distraksi visual, taktil, audiotori, dan intelektual. Terapi musik atau terapi murottal merupakan metode distraksi audiotori yang banyak diteliti.

Terapi musik berguna untuk proses penyembuhan karena dapat menurunkan nyeri dan membuat relaksasi. Rangsangan musik meningkatkan pelepasan endorfin sehingga mengurangi kebutuhan obat analgesik. Musik dapat memperlambat dan menyeimbangkan gelombang otak, bahkan memengaruhi irama pernapasan, denyut jantung, dan tekanan darah (Campbell, Mainos, \& Looney, 2001).

Beberapa penelitian menyebutkan bahwa terapi musik dapat mengurangi intensitas nyeri pada pasien pascabedah pemasangan kateter jantung dan pada pasien fraktur, (Jafari, Zeydi, Khani, Esmaeili, dan Soleimani, 2012 \& Twiss, Seaver, \& McCaffrey, 2006) Liu, Chang, dan Chen (2010) menyebutkan terapi musik menurunkan tingkat nyeri, tekanan darahsistolik, nadi dan berpengaruh juga pada kecemasan.

Hal ini karena musik mempengaruhi sistem limbik yang merupakan pusat pengatur emosi. Dari limbik, jaras pendengaran dilanjutkan ke hipokampus, tempat salah satu ujung hipokampus berbatasan dengan nuklei amigdala. Amigdala yang merupakan area perilaku kesadaran yang bekerja pada tingkat bawah sadar, menerima sinyal dari korteks limbik lalu menjalarkannya ke hipotalamus (Ranggakayo, 2012). Di hipotalamus yang merupakan pengaturan sebagian fungsi vegetatif dan fungsi endokrin tubuh seperti halnya banyak aspek perilaku emosional, jaras pendengaran diteruskan ke formatio retikularis sebagai penyalur impuls menuju serat saraf otonom. Serat tersebut mempunyai dua sistem saraf, diantaranya sistem saraf simpatis dan sistem saraf parasimpatis. Kedua sistem saraf ini mempengaruhi kontraksi dan relaksasi organorgan. Dengan musik maka sistem saraf otonom ini dapat memerintahkan tubuh untuk melakukan relaksasi, sehingga timbulah ketenangan (Tamsuri, 2007).

Mengenai terapi murottal atau pembacaan ayat Al-Qur'an beberapa studi menyebutkan efek yang sama dengan terapi usik. Pada penelitian tiga pria dan dua perempuan, Robb (2000) menemukan bahwa mereka mendapatkan ketenangan sebanyak 65\% ketika mendengarkan murottal meski tidak memahami Bahasa Arab dan tidak diberi tahu bahwa yang diperdengarkan adalah ayat Al Quran. Responden hanya mendapatkan ketenangan sebanyak 35\% ketika mendengarkan alunan bahasa Arab yang bukan dari Al Quran. Izzat dan Arif (2011) mengatakan bahwa terapi murottal dapat menurunkan tekanan darah. Di Pakistan, mendengarkan Al Quran telah dijadikan sebagai salah satu terapi pengobatan untuk berbagai penyakit.

Al-Quran merupakan sarana pengobatan untuk mengembalikan keseimbangan sel yang rusak. Jika mendengarkan musik klasik dapat memengaruhi kecerdasan intelektual (IQ) dan kecerdasan emosi (EQ), maka bacaan Al Quran juga memengaruhi kecerdasan spiritual (SQ) (Shihab, 1998). Penelitian yang dilakukan oleh Sodikin (2012) di RS Cilacap menyatakan terapi bacaan $\mathrm{Al}$-Quran dapat bersinergi dengan terapi farmakologi dalam menurunkan nyeri. Pemberian terapi Al-Quran memberikan efek non farmakologi adjuvan dalam mengatasi nyeri. Hal ini sejalan dengan teori nyeri: Keseimbangan antara analgesik dan efek samping dari Good yang menyatakan bahwa pemberian analgetik akan memberikan efek samping sehingga dibutuhkan terapi komplementer (Rachmawati, 2008).

Ayat Al-Qur'an yang sering dilatunkan sebagai terapi murottal adalah surat Al-Faatihah, Al Ikhlas, Al Falaq, An Naas, ayat Qursy, surat 
Yaasin ayat ke 58 dan Al An'am ayat 1-3, dan 13. Semua surat itu mengaktifkan energi Ilahiyah dalam diri pasien yang dapat mengusir penyakit dan rasa sakit yang diderita (Ramadhani, 2007).

Penelitian tentang efektivitas terapi murottal terhadap nyeri belum banyak dilakukan di Indonesia sebagai negara berpenduduk muslim terbesar di dunia. Tujuan penelitian ini adalah untuk membandingkan antara efektivitas terapi musik dengan terapi murottal terhadap penurunan tingkat nyeri dan kestabilan tanda-tanda vital (tensi, nadi, pernapasan dan suhu tubuh) pada pasien pascabedah.

\section{Metode}

Penelitian kuasi eksperimen dengan pendekatan pretest-posttest control group ini melibatkan 36 responden yang dipilih secara kuota di sebuah rumah sakit di Kabupaten Garut, Jawa Barat. Kriteria inklusi mencakup pasien pascabedah dengan keluhan utama nyeri, belum mendapat obat analgetik, tingkat kesadaran penuh, dan tanda-tanda vitalnya mengalami ketidakstabilan. Kriteria eksklusi yakni memiliki gangguan pendengaran, dan mengalami nyeri sangat hebat. Responden dibagi menjadi 16 orang untuk kelompok terapi musik dan 20 responden untuk terapi murottal. Pasien non-muslim dimasukkan dalam kelompok terapi musik. Vriabel dependen yaitu intensitas nyeri dan kestabilan tanda-tanda vital dan variabel perancu adalah jenis kelamin, pendidikan, pekerjaan dan terapi obat. Masingmasing kelompok sebelum dan sesudah pemberian terapi tingkat nyerinya dinilai menggunakan Numerical rating scales (NRS) 0-10 dan tekanan darah, jumlah nadi per menit, frekuensi pernapasan per menit dan suhu tubuh diukur.

Penelitian ini telah mendapatkan persetujuan etik dan izin administrasi di lokasi penelitian. Penelitian ini dilakukan oleh peneliti yang juga seorang perawat sehingga mempunyai kompetensi untuk merawat pasien pascabedah.

\section{Hasil}

Lebih dari setengah responden berusia antara 20 hingga 40 tahun (52,8\%), laki-laki $(55,6 \%)$, berpendidikan Sekolah Dasar (47,2\%), dan bekerja sebagai buruh $(44,4 \%)$. Karakteristik responden dapat dilihat pada Tabel 1 .

Terdapat perbedaan penurunan nyeri antara terapi murottal dan terapi musik $(\mathrm{p}=0,000)$. Terapi murottal lebih baik dalam menurunkan tingkat nyeri dibandingkan dengan terapi musik (Tabel 2).

Berdasarkan hasil perhitungan, didapat nilai $\mathrm{p}=$ 0,287 . Pengujian akan menolak Ho jika $\mathrm{p}<\alpha$

0,05 . Jika dibandingkan dengan taraf signifikan

Tabel 1. Karakteristik Responden

\begin{tabular}{lcc}
\hline Karakteristik & f & \% \\
\hline Umur & & \\
$<20$ tahun & 8 & 22,2 \\
20-40 tahun & 19 & 52,8 \\
$>40$ tahun & 9 & 25,0 \\
Jenis Kelamin & & \\
Laki-laki & 20 & 55,6 \\
Perempuan & 16 & 44,4 \\
Pendidikan & & \\
SD & 17 & 47,2 \\
SMP & 10 & 27,8 \\
SMA & 9 & 25,0 \\
Pekerjaan & & \\
Buruh & 16 & 44,4 \\
IRT & 8 & 22,2 \\
Pegawai swasta & 2 & 5,6 \\
Pelajar & 6 & 16,7 \\
Tidak bekerja & 1 & 2,8 \\
Wiraswasta & 3 & 8,3 \\
\hline
\end{tabular}

Tabel 2. Perbandingan Efektivitas Terapi Musik dan Terapi Murottal pada Penurunan Nyeri

\begin{tabular}{ccccc}
\hline $\begin{array}{c}\text { Penurunan } \\
\text { Nyeri }\end{array}$ & n & $\begin{array}{c}\text { Jumlah } \\
\text { Ranking }\end{array}$ & $\begin{array}{c}\text { Mann- } \\
\text { Whitney } \\
\text { (uji Z) }\end{array}$ & $\mathbf{p}$ \\
\hline $\begin{array}{c}\text { Terapi } \\
\text { Murottal } \\
\text { Terapi } \\
\text { Musik }\end{array}$ & 20 & 501 & & \\
\hline
\end{tabular}


nilai $\mathrm{p}=0,287$ lebih besar maka Ho diterima. Dengan demikian, tidak terdapat perbedaan penurunan tekanan darah untuk kedua terapi, baik terapi musik dan terapi murottal (Tabel 3).

Berdasarkan hasil analisis, didapat rerata nadi setelah terapi murottal menurun 10 kali per menit dibanding sebelum terapi. Untuk terapi musik, rerata penurunan nadi delapan kali per menit. Hasil pengujian menunjukkan t hitung sebesar 0,697 dan nilai $\mathrm{p}=0,494$. Jika dibandingkan dengan taraf signifikan $\alpha 0,05$ maka nilai $p$ lebih besar sehingga Ho diterima. Ini artinya tidak terdapat perbedaan rerata nadi setelah terapi murottal dan terapi musik (Tabel 4).

Tidak terdapat perbedaan penurunan pernapasan antara terapi murottal dan terapi musik $(\mathrm{p}=0,150)$. Demikian pula pada suhu, tidak terdapat per-

Tabel 3. Perbandingan Efektivitas Terapi Musik dan Terapi Murottal terhadap TandaTanda Vital (dengan Uji T2 Hotelling)

\begin{tabular}{cccc}
\hline Variabel & Nilai & F & Sig. \\
\hline Terapi & 0,078 & $1,295(\mathrm{a})$ & 0,287 \\
\hline
\end{tabular}

Tabel 4. Perbedaan Penurunan Nadi dengan Terapi Musik dan Terapi Murottal (Uji t)

\begin{tabular}{ccccc}
\hline Kelompok & $\mathrm{N}$ & $\begin{array}{c}\text { Rerata } \\
\text { Penurunan } \\
\text { (kali/menit) }\end{array}$ & $\begin{array}{c}\mathrm{t} \\
\text { hitung }\end{array}$ & $\mathrm{p}$ \\
\hline Terapi Murottal & 20 & 10 & & \\
& & & 0,697 & 0,494 \\
Terapi Musik & 16 & 8 & & \\
\hline
\end{tabular}

Tabel 5. Perbandingan EfektivitasTerapi Musik dan Terapi Murottal terhadap Kestabilan Pernapasan dan Suhu

\begin{tabular}{lcccc}
\hline \multicolumn{1}{c}{ Tanda Vital } & $\mathbf{n}$ & $\begin{array}{c}\text { Jumlah } \\
\text { Rangking }\end{array}$ & $\begin{array}{c}\text { Mann- } \\
\text { Whitney } \\
\text { (uji Z) }\end{array}$ & $\mathbf{p}$ \\
\hline $\begin{array}{l}\text { Pernapasan } \\
\text { Terapi Murottal }\end{array}$ & 20 & 414,5 & & \\
Terapi Musik & 16 & 251,5 & $-1,439$ & 0,150 \\
$\begin{array}{l}\text { Suhu } \\
\text { Terapi Murottal }\end{array}$ & 20 & 413,5 & & \\
Terapi Musik & 16 & 252,5 & $-1,422$ & 0,168 \\
\hline
\end{tabular}

bedaan penurunan suhu tubuh antara terapi murottal dan terapi musik $(\mathrm{p}=0,168)$. Lihat Tabel 5.

Sebanyak 30 orang dari total 36 responden dalam penelitian ini mendapatkan terapi analgetik narkotik yaitu tramadol dengan dosis $10 \mathrm{mg} / \mathrm{kg}$ dalam $500 \mathrm{cc} \mathrm{NaCl} 3-5$ jam pascabedah. Sebanyak enam pasien mendapatkan terapi analgetik non narkotik yaitu ketorolak $30 \mathrm{mg}$ 2x1.

\section{Pembahasan}

Hasil penelitian ini mendukung hasil penelitian sebelumnya tentang pengaruh terapi musik dan terapi murottal terhadap penurunan tingkat nyeri dan kestabilan tanda-tanda vital. Penelitian Hanifah (2007) di Kabupaten Blitar menemukan pengaruh terapi musik pada penurunan intensitas nyeri akibat perawatan luka bedah abdomen ( $\mathrm{p}=0,039)$. Bradt et al. (2009) di Inggris menyebutkan bahwa musik memperbaiki suasana hati (mood) pasien pascabedah. Musik menimbulkan perasaan tenang dan rileks sehingga nyeri berkurang.

Selain dapat menurunkan nyeri pada pasien pascabedah, terapi musik dapat menstabilkan tanda-tanda vital seperti tekanan darah, denyut nadi, pernapasan dan suhu. Penelitian di Taiwan oleh Liu et al., (2010) menunjukan bahwa musik dapat menurunkan frekuensi respirasi ireguler secara signifikan. Musik dikatakan sebagai ansiolitik atau agen relaksasi yang efektif. Disimpulkan bahwa musik memberikan keuntungan bagi pasien rawat jalan.

Menurut Campbell et al., (2001) bunyi-bunyian dengan frekuensi sedang cenderung merangsang jantung, paru, dan emosi. Bunyi musik yang bergetar membentuk pola dan menciptakan medan energi resonansi dan gerakan di ruangan sekitarnya. Energi akan diserap oleh tubuh manusia dan secara bertahap mengubah pernapasan, detak jantung, tekanan darah, ketegangan otot, temperatur kulit, dan irama internal lainnya (Mucci \& Mucci, 2000). Twiss et al. (2006) juga mengungkapkan bahwa musik merupakan stimulus yang unik yang memengaruhi respon fisik dan psikologi 
pendengar sehingga menjadi intervensi yang efektif untuk meningkatkan relaksasi fisiologis yang diindikasikan dengan penurunan nadi, respirasi dan tekanan darah.

\section{Efektivitas Terapi Murottal terhadap} Penurunan Tingkat Nyeri dan Kestabilan Tanda-Tanda Vital. Faradisi (2012) di Jawa Tengah menemukan bahwa terapi murottal lebih efektif dibanding terapi musik dalam menurunkan tingkat kecemasan pada pasien pra-bedah. Nurliana (2011) pada penelitian di Medan menemukan bahwa terapi murottal berpengaruh pada penurunan nyeri pada ibu yang dilakukan tindakan kuret. Terapi murottal juga berpengaruh besar pada respon nyeri pada pasien pascabedah hernia di Cilacap (Sodikin, 2012). Sokeh, Armiyati, dan Chanif (2013) menemukan pengaruh yang signifikan pada rerata intensitas nyeri sebelum dan sesudah terapi murottal pada pasien yang terpasang ventilator mekanik.

Melalui terapi pembacaan Al Quran terjadi perubahan arus listrik di otot, perubahan sirkulasi darah, perubahan detak jantung dan kadar darah pada kulit (Asman, 2008). Perubahan tersebut menunjukan adanya penurunan ketegangan saraf reflektif yang mengakibatkan terjadinya vasodilatasi dan peningkatan kadar darah dalam kulit, diiringi dengan penurunan frekuensi detak jantung. Pemberian Terapi bacaan Al Quran terbukti mengaktifan sel-sel tubuh dengan mengubah getaran suara menjadi gelombang yang ditangkap oleh tubuh, menurunkan rangsangan reseptor nyeri sehingga otak mengeluarkan opioid natural endogen. Opioid ini bersifat permanen untuk memblokade nociceptor nyeri.

\section{Perbandingan Efektivitas Terapi Musik dan Terapi Murottal pada Penurunan Tingkat Nyeri dan Kestabilan Tanda-Tanda Vital. Gelombang suara dari pembacaan ayat Al Quran akan masuk melalui telinga, kemudian menggetarkan gendang telinga, mengguncang cairan di telinga dalam serta menggetarkan sel- sel berambut di dalam Koklea. Selanjutnya melalui saraf Koklearis menuju ke otak. Tiga jaras Retikuler yang berperan dalam gelombang suara yaitu jaras retikuler-talamus, hipotalamus.}

Gelombang suara diterima langsung oleh Talamus, yaitu suatu bagian otak yang mengatur emosi, sensasi, dan perasaan, tanpa terlebih dahulu dicerna oleh bagian otak yang berpikir mengenai baikburuk maupun intelegensia. Kemudian melalui Hipotalamus memengaruhi struktur basal forebrain termasuk sistem limbik. Hipotalamus merupakan pusat saraf otonom yang mengatur fungsi pernapasan, denyut jantung, tekanan darah, pergerakan otot usus, fungsi endokrin, memori, dan lain-lain. Selanjutnya, melalui akson neuron berdifusi mempersarafi neo-korteks (Qadri, 2003).

Mendengarkan bacaan Al Quran lebih bermanfaat dibanding mendengarkan suara lain seperti musik. Suara Al Quran meredakan stress dan meningkatkan ketahanan terhadap stress, meningkatkan relaksasi, ketenangan dan kenyamanan, membantu mengatasi insomnia, meningkatkan imunitas, dan meningkatkan kecerdasan spiritual.

Zulkurnaini, Kadir, Murat, \& Isa (2012) mengungkapkan bahwa mendegarkan bacaan ayat suci Al-quran memiliki pengaruh yang signifikan dalam menurunkan ketegangan urat saraf reflektif, dan hasil ini tercatat dan terukur secara kuantitatif dan kualitatif oleh sebuah alat berbasis komputer. Adapun pengaruh yang terjadi berupa adanya perubahan arus listrik di otot, perubahan daya tangkap kulit terhadap konduksi listrik, perubahan pada sirkulasi darah, perubahan detak jantung, dan kadar darah pada kulit. Perubahan tersebut menunjukkan adanya relaksasi atau penurunan ketegangan urat saraf reflektif yang mengakibatkan terjadinya vasodilatasi dan penambahan kadar darah dalam kulit, diiringi dengan peningkatan suhu kulit dan penurunan frekuensi denyut jantung.

Kemajuan tehnologi telah mendeteksi secara akurat bahwa mendengarkan ayat-ayat Al Quran dapat merelaksasi saraf reflektif, memfungsikan organ tubuh, serta memberikan aura positif pada tubuh manusia. Bacaan Al-Quran berefek pada sel-sel dan dapat mengembalikan keseimbangan. Otak merupakan organ yang mengontrol tubuh, dan darinya muncul perintah untuk relaksasi tubuh, khususnya sistem imunitas (Sokeh et al. 2013). 
Hasil penelitian ini menunjukkan bahwa terapi murottal lebih efektif menurunkan nyeri dibandingkan terapi musik. Ini dapat terjadi karena terapi murottal membantu individu untuk mengembangkan koping mengatasi nyeri. Koping diperlukan sebagai antisipasi terhadap kecemasan dan stres akibat kondisi nyeri. Lantunan ayat Al-Quran mengandung aspek spiritualitas yang membuat individu mengingat Tuhan sehingga menimbulkan rasa cinta atau keimanan. Kecintaan kepada Tuhan ini dapat membangkitkan semangat dalam mengembangkan koping yang positif untuk menghadapi nyeri (Qadri, 2003).

Sodikin (2012) mengungkapkan bahwa terapi bacaan Al-Quran dapat bersinergi dengan terapi farmakologi dalam menurunkan nyeri. Pemberian terapi Al-Quran memberikan efek non-farmakologi adjuvant dalam mengatasi nyeri. Hal ini sejalan dengan teori nyeri dari Good yang menyatakan bahwa perlu adanya keseimbangan antara pemberian analgetik dengan efek samping sehingga dibutuhkan terapi adjuvant (Rachmawati, 2008).

\section{Terapi Musik dan Terapi Murottal Tidak} Memiliki Efektivitas Dalam Menstabilkan Tanda-Tanda Vital. Hasil penelitian ini tidak menemukan efek terapi musik dan murottal terhadap kestabilan tanda-tanda vital. Hal ini mungkin terjadi akibat pemberian obat analgetik. Obat golongan analgesik akan merubah persepsi dan nilai tanda-tanda vital dengan jalan mendepresi sistem saraf pusat pada talamus dan korteks cerebri. Pemberian tramadol dalam dosis besar, dapat mengakibatkan depresi miokard atau hipotensi, mencerminkan adanya penurunan respon kompensasi sistem saraf simpatik. Sebagai contoh, tramadol menurunkan tonus sistem saraf simpatis pada vena perifer, sehingga mengakibatkan pengumpulan darah di vena dan selanjutnya menurunkan aliran balik vena, curah jantung, denyut nadi, dan tekanan darah (Stoelting, 2006).

\section{Kesimpulan}

Terapi musik dan terapi murottal memiliki efek terhadap penurunan tingkat nyeri tetapi tidak memiliki efek yang signifikan terhadap kestabilan tanda-tanda vital pada pasien pascabedah. Terapi murottal memiliki efektivitas lebih baik dibandingkan terapi musik terhadap penurunan tingkat nyeri tetapi tidak memiliki efek terhadap kestabilan tanda-tanda vital pasien pascabedah (YS, INR).

\section{Referensi}

Apfelbaum, J.L., Chen, C., Mehta, S.S., \& Gan, T.J. (2003). Postoperative pain experience: Results from a national survey suggest postoperative pain continues to be undermanaged. Anesthesia \& Analgesia, 97(2), 534-540. doi: 10.1213/01.ane.0000068822. 10113.9e.

Asman, O. (2008). Qur'anic healing for spiritual ailments, between tradition, religious law and contemporary law. Medical Law Journal, 259-284.

Bradt, J., Dileo, C., \& Potvin, N. (2013). Music for stress and anxiety reduction in coronary heart disease patients. Cochrane Database Syst Rev, 12.

Campbell, M, Mainos R.O.,\& Looney, S.W (2001). Effect of music on anxiety ofwomen awaiting breast biopsy.British Journal, 4(3); 128-137.

Elzaky, J. (2011). Mukjizat kesehatan ibadah. Jakarta: Penerbit Zaman.

Faradisi, F. (2012). Efektivitas terapi murotal dan terapi musik klasik terhadap penurunan tingkat kecemasan pasien pra-operasi di Pekalongan. Jurnal Ilmiah Kesehatan, 5(2) Diperoleh dari: http://www.journal. stikesmuhpkj.ac.id/journal/index.php/jiks/ article/.

Hanifah, (2007). Pengaruh terapi musik terhadap intensitas nyeri akibat perawatan luka bedah abdomen di Badan Pelaksana Kesehatan Masyarakat RSU Ngudi Waluyo Wlingi Kabupaten Blitar. Skripsi Tidak Dipublikasi. PSIK-FK Universitas Brawijaya Malang.

Izzat, A.M., \& Arif, M. (2011). Terapi ayat AlQur'an untuk kesembuhan: Keajaiban AlQuran menyembuhkan penyakit. Solo: Kafilah. 
Jafari, H., Zeydi, A.E., Khani, S., Esmaeili, R., \& Soleimani, A. (2012). The effects of listening to preferred music on painintensity after open heart surgery. Iranian Journal of Nursing andMidwifery Research, 17(1), 16.

Liu, H.Y., Chang, Y.M., \& Chen, H. C. (2010). Effects of music theraphy on labour pain and anxiety in Taiwanese first-time mothers. Journal of Clinical Nursing, 19(7-8), 10651072.

McGrath, B., Elgendy, H., Chung, F., Kamming, D., Curti, B., \& King, S. (2004). Thirty percent of patients have moderate to severe pain $24 \mathrm{hr}$ after ambulatory surgery: A survey of 5,703 patients. Canadian Journal of Anesthesia, 51(9), 886-891. doi: $10.1007 / \mathrm{bf} 03018885$

Mucci, R.J., \& Mucci, K.L. (2000). The healing sound of music. The Park, Forres, Scotland: Findhorn Press.

Nurliana. (2011). Efektifitas perangsangan auditori ayat-ayat suci Al-Quran terhadap kecemasan ibu yang sedang dilakukan kuret di RSUD Dr. Pringadi Medan. Diperoleh dari: http://repository.usu.ac.id/.

Pacagnella, R. C., Souza, J. P., Durocher, J., Perel, P., Blum, J., Winikoff, B., \& Gülmezoglu, A. M. (2013). A Systematic review of the relationship between blood loss and clinical signs. PLoS One, 8(3), e57594. doi: 10.1371/journal.pone.0057594.

Qadri, M.A. (2003). Quranic therapy heal yourself. California: Islamic Educational Cultural Research Center of North America. Diperoleh dari: http://www.iecrena.org/ publications/books/.

Rachmawati, I.N. (2008). Analisis teori nyeri: Keseimbangan antara analgesik dan efek samping. Jurnal Keperawatan Indonesia, 12(2), 129-136.

Ramadhani, E.Z. (2007). Super health: Gaya hidup sehat Rasulullah. Yogyakarta: Pro-U Media.
Ranggakayo. (2012). Mekanisme penanganan nyeri dengan menggunakan terapi musik. Surabaya: Media Mustika.

Robb, S.L. (2000). Murottal assisted progressive muscle relaxation, progressive musclerelaxation, music listening, and silence: A comparison on relaxation techniques. Journal of Music Therapy, 37(1), 2-21.

Sodikin., Irawaty, D., \& Sukmarini, L. (2012). Pengaruh terapi bacaanAl-Quran melalui media audio terhadap respon nyeri pasien post operasi herniadi RS Cilacap. Tesis Magister FIK UI, Depok. Diperoleh dari: http://lib.ui.ac.id/file?file $=$ digital/2030791 3-T\%2031400-Pengaruh\%20terapi-full\%20text.pdf

Sokeh, Armiyati, Y., Chanif. (2013). Prosiding Konferensi Nasional PPNI Jawa Tengah 2013: Pengaruh perangsangan auditori murrotal (ayat-ayat suci Al Qur'an) terhadap nyeri pada pasien yang terpasang ventilator mekanik di Ruang ICU RS Islam Sultan Agung Semarang. Semarang: Unimus.

Stoelting, R.K., \& Hillier, S.C. (2006). Opioid Agonists and Antagonists, Local Anesthetics, Cyclooxygenase-2 Inhibitorand Nonspecific Nonsteroidal Antiinflammatory Drugs. In: Pharmacology \& Physiology in Anesthetic Practice. 4th ed. Philadelphia: Lippincott Williams \& Wilkins.

Tamsuri, A. (2007). Konsep dan penatalaksanaan nyeri. Jakarta: EGC

Twiss, E., Seaver, J., \& McCaffrey, R. (2006). The effect of music listening on older adults undergoing cardiovascular surgery. Nursing in Critical Care, 11(5), 224-231.

Zulkurnaini, N.A., Kadir, R.S.S.A., Murat, Z.H., \& Isa, R.M. (2012, February). The comparison between listening to al-Quran and listening to classical music on the brainwave signal for the alpha band. In Intelligent Systems, Modelling and Simulation (ISMS), 2012 Third International Conference on (pp. 181-186). IEEE. 